DOI: https://doi.org/10.18524/2519-2523.2018.13.149389

УДК 94(477.7)"19/20»

\title{
COSSACKS SUBDIVISION IN THE GIGANTIC POLITICAL SYSTEM AND EVERYDAY LIFE BETWEEN THE TWO ROSSIAN-TURKISH WARS IN THE FIRST THIRD OF XIX C. (ACCORDING TO THE DOKUMENTS OF STATE ARCHIVES OF THE ODESSA REGION)
}

\section{Olena Bacynska}

DSc (History), Professor

Odessa I. I. Mechnikov National University

2, Dvoryanska Str., Odessa, 65082, Ukraine

Olena_an@ukr.net

In the publication, readers are offered documents that reveal the everyday life of "Turkish" Cossacks - Zaporozhian and Nekrasov - on the Ottoman-Russian border, as well as localize their location in the Danube region in early XIX century. The proposed materials are correspondence between the Russian and Ottoman administrations to delimit the borders after two Rusian-Turkish wars of 1806-1812 and 1828-1829, maps of the placement of the Danube and Nekrasov Cossack fishermen. They allow us to find out that between Cossacks of different groups there were close contacts on the economic basis, largely preserved by the Ottoman border authorities and the commandants (Naziri) of the Danube fortresses. At the same time, the Russian border administration tried to oust the "Turkish" Cossack fishermen to avoid communicating with their relatives in Danube towns and fortresses.

Documents are published for the first time.

Key words: Necrazousky (Kuban) Cossacks, Danube (Turkish) Zaporozhye Cossacks, Danube, Russian-Turkish War of 1806-1812, Russian-Turkish War of 1828-1829, Island of Letti, Chetaly Island, State Archives of Odessa region.

Олена Бачинсъка

Доктор історичний наук, професор Одеський національний університет імені I. I. Мечникова Вум. Дворянська, 2, Одеса, 65082, Україна Olena_an@ukr.net

\section{КОЗАЦЫКЕ ПОРУБІЖЖЯ У ВЕАИКІЙ ПОАІТИЦІ ТА ПОВСЯКДЕННІ МІХК ДВОМА РОСІЙСЫКО-ТУРЕЦЫКИМИ ВІЙНАМИ ПЕРШОЇ ТРЕТИНИ ХІХ СТ. (за матеріалами Держархіву Одеської обцасті)}

У публікаиії до уваги читачів пропонуються документи, які розкривають повсякденне життя “туреиьких" козаків - запорозьких та некрасівських - на османсько-російському кордоні, а також локалізують місия їхнього розташування у Подунав'i початку XIX $\mathrm{cm}$. Запропоновані матеріали являють собою листування російсъкої та османсъкої адміністраиї иодо розмежування кордону між двома російсъко-туреиькими війнами 18061812 рр. та 1828-1829 рр., карти розмішення задунайських та некрасівських козаиьких рибалок. Вони дозволяють з'ясувати, шо міжк козаками різних груп залишалися тісні контакти на господарському підгрунті, багато в чому їх зберігала османсъка прикордонна адміністрації та коменданти (назирі) 
дунайсъких фортеиъ. В той самий час російсъка прикордонна адміністраиія намагалась витіснити "турецьких" рибалок-козаків, шоб запобігти їхнъому спілкуванню з родичами у дунайських містах та фортеиях. Документи публікуються вперше.

Ключові слова: некрасівські (кубанські) козаки, задунайські (туреиькі) запорожиі, Дунай, російсъко-туреиъка війна 1806-1812 рр., російсъкотуреиька війна 1828-1829 рр., острів Аеті, острів Четал, Державний архів одеської області.

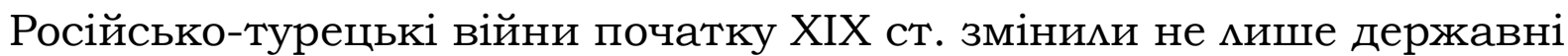
кордони між Османською державою та Російською імперією, але й внесли корективи у повсякденне життя населення Подністров'я та Подунав'я. Внаслідок війни 1806-1812 рр. кордон між імперіями був установлений по р. Дунай, що зумовимо міграційні процеси в Буджаку. Це зрозуміло, адже під час воєнних дій населення мало, в першу чергу, зберегти життя, а після цього відповісти на питання про подальше проживання і становище в рамках помітики нової держави - Російської.

На території Буджака та Добруджі під вцадою двох держав проживали українські запорозькі козаки та російські козакистарообрядці. Перші відомі під назвою задунайські (турецькі) запорожці, другі - некрасівські (донські або кубанські) козаки. Більшість поселень цих груп козаків розташавувались саме у прикордонних областях, а їхні господарські заняття були пов'язані 3 рибальством у гирлі річки Дунаю. Стосунки між цими двома групами були досить різні, здебільшого, як не безпідставно вважають досмідники, вони мали суперечки через місця рибних мовів. Одночасно на стосунки між запорожцями й некрасівцями вплинула й кризова ситуація у середині османських володінь 1780-х - початку XIX ст., пов'язана з реформаторською діяльністю султана Селіма III (1789-1808) в галузі управління, економіки, військової справи, армії. В цей час з'явимись симьні та свавільні аяни, які не підтримували реформи султана і послабляли авторитет центральної влади. Серед противників реформ був в Ізмаїлі двобунчужний паша Ібрагім Пеглеван. Задунайські запорожці боролися у складі турецьких урядових частин з зазначеними феодалами понад вісім років разом 3 прихильними до султана керівниками Добруджі і Румемії. У свою чергу, некрасівські козаки підтримували Ібрагіма Пеглевана. За свідченням задунайця Миколи Діброви, паша Пеглеван, якому підпорядковувались некрасівські козаки "не давав їм (запорожцям - О.Б.) спокою, усі запорожці перебрались із Сеймен у Вимкове та Катирлез на землю визначену їм від браїцьського назиря та проживали тут до трьох років” [2, с. 108]. Однак довго тут козаки не протримались. Некрасівці у складі військ ізмаїцьського паші здійснили напад на Січ задунайців у Катирлезі, Січ та житла козаків спалили. Внаслідок таких подій задунайці змушені були перебратися до фортеці Браїла під захист назиря (коменданта). Про це збереглось чимало свідчень, як російських розвідників, так і самих задунайців. Самі задунайці не залишились осторонь таких дій i, як відомо, після російсько-турецької війни 1806-1812 рр. вирушили на некрасівські поселення i зайняли їх головний центр - c. Верхній 
Дунавець на Георгіївському гирлі, там де і заклали Січ (тепер с. Верхній Дунавець (Dunavățu de Sus) в повіті Тульча (Румунія)).

Бухарестський мир 1812 р. чітко не визначив, як має проходити кордон між двома державами в пониззі Дунаю. Так, стаття IV проголошувала: “...река Прут со входа ее в Молдавию до соединения ее с Дунаем и мевый берег Дуная с сего соединения до устья Кимийского и до моря, будут составмять границу обеих империй, дмя коих устье сие будет общее. Небольшие острова, кои до войны не были обитаемы, и начиная напротив Измаила до помянутого устья Килийского находятся ближе к мевому берегу, имеющему принадлежать России, не будут обладаемы ни единой из обеих держав, и на оных впредь никаких не демать укреплений, ни строений, но островки сии останутся пусты, и обоюдные подданные могут туда приезжать единственно дия рыболовли и рубки меса. Стороны двух больших островов, межащих напротив Измаила и Килии, также пустыми и незаселенными останутся пространством на час расстояния, начиная с самого ближайшего пункта помянутого цевого берега дунайского; пространство сие будет означено знаками, а жилища до войны бывшие, равно и старая Килия, останутся за сей порубежной чертой. Вследствие вышепомянутой статьи, Блистательная Порта Оттоманская уступает и отдает Российскому Императорскому двору земли, межащие по мевому берегу Прута, с крепостями, местечками, селениями и жилищами, тамо находящимися, средина же реки Прута будет границей между обеими высокими империями" [1].

Як видно з тексту Бухарестського миру 1812 р. кордон проходив по Кілійському гирлу Дунаю. У 1817 р., після спеціальної угоди 3 Портою мали провести більш чітку иінію кордону по Сулинському гирлу,

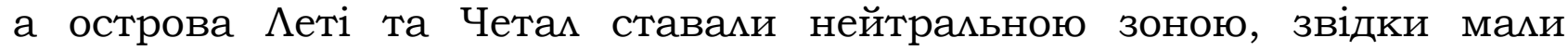
виселити всіх запорозьких рибалок до Сулинського гирла, де не було для них зручних місць дмя рибного мову і відомих торговецьних міст, таких як Ізмаїл і Кілія. Установлення кордону в гирлах Дунаю зустріло опір населення, як з російського, так і з турецького боку. Так, у 18161817 pp. некрасівські козаки і турецькі запорожці, яким допомагали місцеві жителі Вилкового з “криками, цайками і глузуваннями" мамали установцені прикордонні межі [10, арк. 56, 159]. Докумети, що збереглися в Державному архіві Одеської області і запропоновані до уваги читачів теж свідчать, що процес встановлення кордону був складним, заплутаним та болючим. Його вирішення тягнулось до початку наступної російсько-турецької війни 1828-1829 рр. [7]. Ця, здавалось би мікроісторична ситуація, боротьба козаків за збереження традиційного господарського способу життя впливала в подальшому на військово-політичне становище в регіоні.

Зазначемо, що складність визначення кордону на Дунаї піднімалось в історіографії неоднаразово, зокрема, в роботах істориків Г. С. Гросула, В.Я. Гросула, Є. Чертана, російських діячів ХІХ ст. М. Богдановича, О. Петрова, О. Аанжерона та інших $[3 ; 4 ; 5 ; 6 ; 7 ; 8 ; 11$; 12 та інші]. Більшість із них торкались дипломатичних переговорів i 
загальної європейської політики, політичної ситуації навколо Дунайських князівств, російсько-турецьких війн XIX ст. У даній публікації увага звертається на ситуацію, що склалась у житті козацького та іншого населення в прикордонні та спроби російської i османської вцади їі розв'язати.

Згадані вище документи Державного архіву запропоновані до уваги читачів містяться у справі “Дело о разграничении Дунайских островов дмя опредемения границы между Россиею и Портою Оттоманскою, тут вся переписка по демам пограничным. 8 сентября 1816. Кончено 28 февраля 1828 г. На 405 мистах" [7]. Справа хронологічно роздінена на дві частини: перша 31816 р. до 1827 р. та друга - 3 1827-1828 pр. Документи справи можна поділити на декілька тематичних груп, які дають можливість переосмислити вже відомі факти, а також мають нові невідомі до сьогодні моменти історії повсякдення на Дунайському прикордонні. Окремі з них запропоновані читачам у додатках до даної пубцікаціі.

Перша група документів стосується мистування вищих керівників Російської держави та посланників Росії в Османській імперії щодо проведення чіткого кордону згідно зі згаданою вище IV статтею Бухарестського миру 1812 р., російсько-турецької комісії серпня 1817 р. та Аккерманської конвенції жовтня 1826 р. Тут збереглися мисти російських послів у Стамбулі А. Я. Італінського, Г. О. Строганова, O. I. Рібоп'єра до намісників Бессарабскої області О. М. Бахметьєва та I. М. Інзова, новоросійського та бессарабского генерал-губернатора М. С. Воронцова, одеського градоначальника Ф. П. Палєна та інших. Аисти дають уявлення про роль місцевого керівництва, що безпосередньо брало участь в регуляції складних стосунків між жителями правого i мівого берегів Дунаю та намагалось незважаючи на непрості умови провести мінію розмежування, зокрема, місцевих керівників карантинних та прикордонних установ, керівників Дунайської фмотілії капітана С. А. Попандопуло, капітана Һобисевича, капітана Заводовського та брандвахтених офіцерів - лейтенанта Мойсеєва, мейтенанта Аевицького та інших (див. документи додатка). 3 османського боку також керівники прикордонних фортець намагались врегулювати питання кордону, зокрема активну роль у цьому брав двобунчужний тульчинський паша Юнус (див. додаток док. № 15, № 18). Всі запропоновані рапорти та мисти цих чиновників розкривають чи не щоденний живий манцюг подій у прикордонні: переміщення некрасівських козаків (в тексті документів названі турецькими кубанцями), запорозьких козаків або місцевого населення.

Друга група документів характиризує повсякденне життя козаків і жителів прикордонних міст і фортець, їхні щоденні потреби, стосунки, міграціі. Так, зокрема, з мипня 1817 р. російські прикордонні служби інформують про поселення кубанців на островах Кілійських гирл, що мають залишатися нейтральними. Перенесення Старої Кімії, за рішенням комісії 1817 р., змусило населення шукати іншого притулку і, навіть, втечі на російській бік Дунаю. Так, в березні 1818 р. до карантину “втекли 
3 молдованина, одна жінка 3 двома дітьми, вони оголосили, що турки змушують жителів Старої Кілії переселятися до Тульчі та Преслава", незважаючи на певні засіви хліба, що злишаються. Вони повідомили, що ще до 20 мітніх мюдей просять пашу звіньнити їх" [7, арк. 31a].

3 цієї групи документів дізнаємось про те, що незважаючи на загострені стосунки між некрасівцями та запорожцями - тут на островах дельти Дунаю вони мирно рибалили разом i, скоріше за все, саме російські та османські чиновники створювали напругу через постійне втручання в їхні господарські справи через бажання зробити острови нейтральними та незаселеними (див. документи додатка). Зазначимо, що дані документи свідчать про тісний зв'язок між некрасівцями та запорожцями в господарських справах, наприклад у 1821 p. 11 рибальских каюков "с неводами и посудой, на коих хозяева и работники все некрасовцы и запорожцы, кои при опросе объявили: что они следуют до своих рыбалок из селений Пилипонское и Коска" (7, арк. 145). Часто ці дві категорії козаків в документах фігурують просто як “турецькопіддані рибалки".

Новим виглядає факт, що османська сторона мала спеціального наглядача за рибалками в гирлах Дунаю - вамиша (рум.-митник), який розподіляв рибальські місця та брав податки, а також новими є моменти боротьби кубанців з рибалками селища Вилкове. Останнє, зокрема, у квітні 1821 р. спричинило скаргу жителів Вилкового про те, що турецькі рибалки забрали їхні рибальські речі, і у зв'язку з тим, що османський чиновник та вамиш будуть вітсутні через "возмущения греков против турков", означені рибалки можуть вподальшому чинити утиски вилковським жителям. Ці турецькі рибалки вже зіпсували та забрали рибальського приладдя у Аіфанія Румчирова на 120 мевів, Власа Кареля на 90 мевів, Зіновія Григор'єва та Семена Тарана - на 60 мевів [7, арк. 151-152]. В подальшому турецькі кубанці навмисно псували місцевим прикордонним жителям 3 російського боку рибальське приладдя та неприховано виганяли їх з рибальських місць (див. додаток док. № 16).

За матеріалами справи отримують підтвердження відомості щодо побоювання російської адміністрації, що перебування кубанців та запорожців на остовах дельти Дунаю має не мише господарське значення, але й важливість постійного зв'язку та спілкування з їхніми родичами з російського боку для переходу до них на османський бік (див. документи додатка).

Важливою інформацією можуть бути повідомлення про кошових отаманів Задунайської Січі, іхню комунікацію 3 османською адміністрацією, повідомлення про нові імена старшини.

Повсякденне життя жителів Кілії та Ізмаїла потребувало топлива, сіна, Аісу через, що вони, як показують документи зазначенної справи, звертались до керівництва з проханням заготівлі лісу на островах $е$ еті та Четал [7, арк. 180, 222, 199-200]. Зокрема, у жовтні 1821 р. жителі Кілії

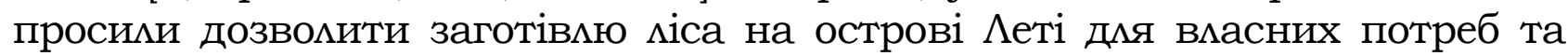
влаштування "Алеї Сцави" в місті [7, арк. 167]; у мипні 1822 р. на 
ізмаїльській портовій карантинній заставі затримали через вирубку міса на острові напроти села Кислиця жителів села Долукіой - болгар Степана Николаєва, Афанасія Славу та українця Івана Бреславського [7, арк. 181].

Третя група документів являє собою діяльність призначеного російським урядом у 1816 р. для розмежування кордону інженераполковника I. Ф. Богдановича та значні ускладнення щодо встановлення цієї мінії, яка так і не була проведена [7, арк. 4, 6, 18]. (Зображення розмежувальної піраміди див. с. 81). Найцікавішим з документів групи $\epsilon$ карта із зазначенням найбільш важливих для прикордонних жителів місць рибальства і розміщення їхніх поселень (див. карту, с. 86-87). Подібна діяльність щодо розмежування кордону активізувалась через 10 років, і як видно з документів, у 1826 р., спеціально до Ізмаїла прибув російський полковник фон Русе, а 3 турецького боку Капичі паша, контролював ситуацію сілістрінський сераскір Хаджи Ахмет Чауш баша. Однак у січні 1828 р., за наказом Головнокомандуючого 2-ю російською армією генерала ад’ютанта П. Д. Кисельова полковник фон Русе мав послатися на погіршення здоров'я і необхідність мікування, та терміново залишити Ізмаїл. Як відомо ускладнення стосунків 3 Османською державою призвели до початку нової війни у квітні 1828 р.

Під час цієї нової війни в травні 1828 р. кошовий отаман задунайських запорожців Йосип ГАадкий перейшов на бік російської армії та цим завершив існування Задунайської (Дунавецької) Січі в Добруджі. Сталося це через те, що протягом 20-х років XIX ст. криза в середині Османської імперії і складна міжнародна ситуація викликала плани імперії перенести Задунайську Січ подалі від кордонів, в далеку Анатолію. Це вплинуло на настрої задунайців через невизначеність свого становища. Одночасно Російська імперія готувалась до нової війни з Портою і вже з 1821 р. в Головному Штабі відпрацьовувались проекти і маршрути руху російської армії на Дунай і Бамкани, у 1826 р. ці плани стрімко активізувались через підвищену увагу європейської спільноти до грецького питання. Однією з проблем, що очікувала російських військових керівників, була незначна кількість флотиліі, яку вони могли надіслати на Дунайський театр війни, неспроможність їі маневру в дунайських гирлах, відсутність необхідних знань про заплави, протоки та єреки, тобто місцевість, де планувалось воювати. В той самий час такі знання, а також мегкі чайки і дуби мами задунайські запорожці, i, як вважають дослідники, при вмілому використані їх у скмаді турецької армії можна було б взагалі заблокувати дії російської армії [9, с. 71-75]. Саме це підтверджує мистування начальника Головного штабу російських військ I. Дібіча 3 новоросійським генерал-губернатором Михайлом Воронцовим у 1826 р. Так, I. Дібіч зазначав, що задунайські запорожці “можуть нанести в

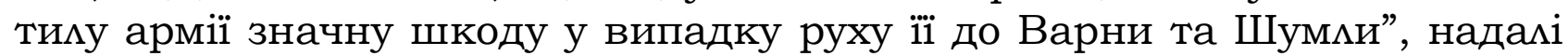
він просив надати відомості про задунайців та пропозиції щодо заходів “на випадок війни з Турками, які можливо було б здійснити дмя винищення або переселення їх в межі Російської імперії або затримки в своїх будинках". На цей запит Михайло Воронцов відповів: “Ми маємо в 
Бессарабії та в Одесі таких Аюдей, які користуються значним впливом на турецьких запорожців і через них уряд намагається тепер все більше

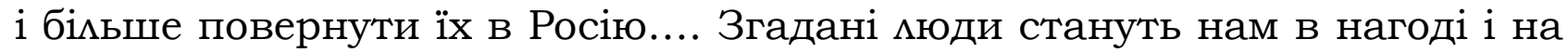
випадок війни вони зможуть привернути на наш бік турецьких запорожців, які надзвичайно дмя нас будуть корисні зі своїми дрібними човнами... Запорожці вміло ведуть свої човни, і на Дунаї не може бути краще дрібної фмотилії ніж з їх човнів" [2, с. 141].

Таким чином, запропоновані до уваги читача та проаналізовані документи дозволяють схарактеризувати напружену ситуацію по розмежуванню дунайського кордону між двома російсько-турецькими війнами 1806-1812 pр. та 18128-1829 рр. З'ясувати роль даного розмежування, вплив на його проведення турецьких запорожців i некрасівців, що проживали на території прикордоння та місцевих жителів османських і російських сіл та фортець. Щоденне життя цих Аюдей було порушено великою політикою і вони намагались пристосуватися до нових умов усіма можливими засобами, що досить часто не задовольняло місцеву прикордонну адміністрацію двох держав.

$* * *$

Подані нижче документи публікуються вперше, популярним методом, зі збереженням мовних, граматичних та стилістичних особливостей оригіналу (в тому числі граматичних помилок). Старі кириличні мітери “i” та “b” замінені відповідними мітерами "и" та "e", твердий знак в кінці слів не пишемо. Непрочитані слова позначені трьома крапками у квадратних дужках.

Документи:

Документ № 1. Рапорт від капітана 1-го рангу С. А. Попандопуло до намісника Бессарабської області О. М. Бахметьева. 21 червня 1817 р. Фортеия Ізмаїл. Оригінал. (арк. 25-25 зв.)

Его Высокопревосходительству Господину генерал-лейтенанту полномочному наместнику Бессарабской области Подольскому военному губернатору и кавалеру Алексею Николаевичу Бахметьеву

Фцота капитана 1-го ранга Попандопумо

Рапорт

Турецкоподданные кубанцы поселившиеся на островах межащих в самых устьях Кимийского Дунаю у вилковских жителей занимавшихся рыбным промыслом нередко воруют рыболовную их посуду, как этим и рапортом моим от 14 апреля №70, об этом уведомили находящегося над теми рыбалками турецкого чиновника так называемого вамыша от коего на то, на турецком диалекте получим отзвыв, которог они в вилков, ни в измаиле никто перевести не мог.

Капитан 1-го ранга Попандопуло 
Документ № 3. Рапорт від капітана 1-го рангу С. А. Попандопуло до намісника Бессарабсъкої області О. М. Бахметъєва. 6 көімня 1818 р. Фортеця Ізмаїл. Оригінал. (арк. 34-35)

Его Высокопревосходительству Господину генерал-лейтенанту полномочному наместнику Бессарабской обцасти Подоцьскому военному губернатору и кавалеру Алексею Никомаевичу Бахметьеву

Фцота капитана 1-го ранга Попандопумо

Рапорт

По достоверным известиям на острове Четале никаких жителей и заведений действительно не имеется. - Кроме что между сим островом и другим в миманах реки Шонды имеются зимой и метом рыбалки. Жители из Старой Кимии почти все переселены в разные места в Тульчу, Прислав и Бештепе со своим имуществом, оставцяя только некоторое количества своего скота на хуторах с чебанами для корму до первого теплого времени, а домы еще существуют и некоторые и теперь заняты хлебом, а в других живут 20 турок при одном аге, присланные от правительства для побуждению жителей к скорейшему переселению в назначенные им места и коль скоро все остальное будет погружено на суда дмя сего идущие тогда турки превратят все здания в пепем.

Находящиеся между килийским и сулинским Дунаем на восточную

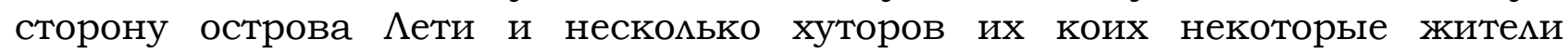
переправившись за сулинский Дунай, а малая часть оных остались на сем острове, по причине холодного времени и худости своего скота, которого теперь переправить в плавь за Сулинский Дунай не могут, но вскоре и оные переведут. Так же на острове семейств и одиноких жителей с разными хозяйственными заведениями около одного места называемого [Чигин] Ерик, кои имеют кузницу и жгут немалое количество угодья. Против Кимийского устья на островах вверх по Дунаю до крепости Кимия турецкоподданные рыбалки ежедневно прибавляються из разных, а большою частию приходят из селений, что выше крепости Браила.

На упомянутых островах умножающиеся кубанцы имеют и вамщика, который поставлен от браицовского паши из военных чиновников, а не откупщика.

Впрочим в какое время что будет происходить на означенных островах непремину донести Вашему Высокопревосходительству.

Фцота капитан Папондопумо

Документ № 4. Рапорт від капітана 1-го рангу С. А. Попандопуло до намісника Бессарабсъкої області О. М. Бахметьєва. 20 липня 1818 р. Фортеия Ізмаїл. Оригінал. (арк. 73-73зв.)

Его Высокопревосходительству Господину генерал-лейтенанту полномочному наместнику Бессарабской области Подоцьскому военному губернатору и кавалеру Алексею Николаевичу Бахметьеву

Фцота капитана 1-го ранга Попандопумо

Рапорт

После донесения моего отправленного к Вашему Высокопревос-

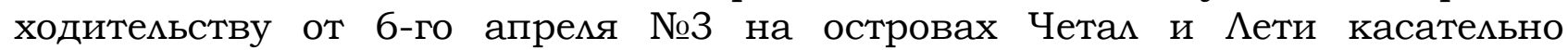
перемещения с оных жителей по сие время перемен не последовало, кроме что на малые острова против Килийских устьев межащие, турецкоподданные 
Зображення кам'яної піраміди для розмежування кордону, розробленої полковником I. Ф. Богдановичем (арк. 48)

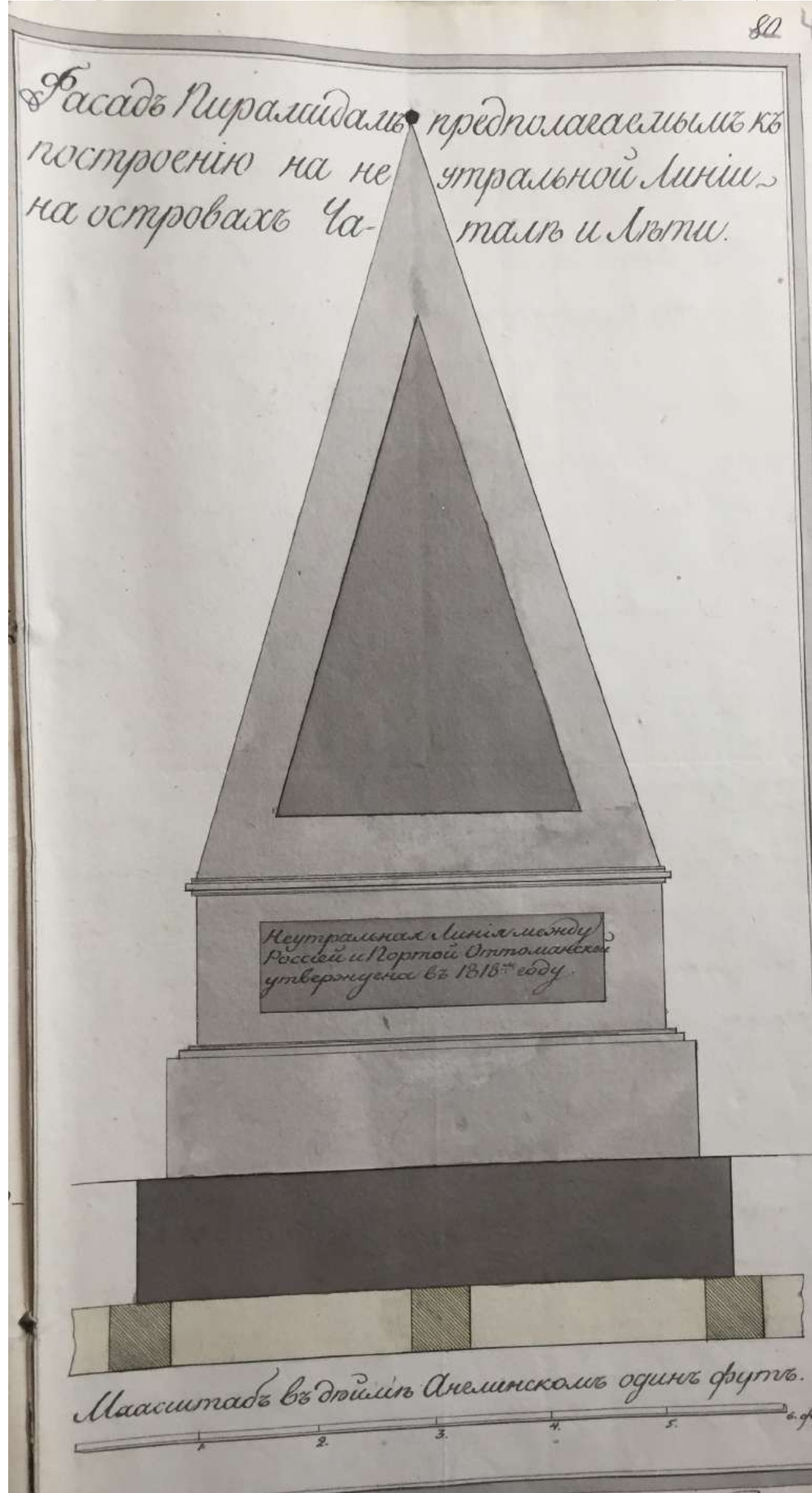


рыбалки прибавляются, а другие из них оттоль уезжают. Относительно селения Старой Кимии, то сего м-ця 9 и 13 числа две партии молдован до 70-ти человек с 40 мошадьми по бимету Тульчинского паши прибыли берегом и на каюках к брантвахте занимающей пост у острова Четала против речки Репиды и объяснили, что они следуют в Старую Килию, для собирания хлеба, посеянного там весною, которые тогда же и пропущены, где и ныне они сим занимаются, о чем Вашему Высокопревосходительству на предписание от 10-го сего м-ця № 2064 почтейнейше донести честь имею в прочем, что будет происходить впредь на означенных островах непремину подробно доносить Вашему Высокопревосходительству.

Фцота капитан Попандопумо

Документ № 5. Рапорт від капітана 1-го рангу С. А. Попандопуло до намісника Бессарабської області О. М. Бахметьєва. 21 көітня 1819 р. Фортеия Ізмаӥл. Оригінал. (арк. 90-91 зв.)

Его Высокопревосходительству Господину генерал-лейтенанту полномочному наместнику Бессарабской области Подоцьскому военному губернатору и кавалеру А^ексею Николаевичу Бахметьеву

Фцота капитана 1-го ранга Попандопумо

\section{Рапорт}

По достоверным сведениям узнано, что турецкоподданых рыбаков дия производства рыбной мовли собралось ныне на Коске двух островов в Стамбульских гирлах до 60 модок, где на прежних местах устроены ими и балаганы. Равно и по Дунаю между островами в Гирлах, начиная от речки Шонды вниз по течению, также рыбная мовля по правому берегу [на Четале] производится. - На островах Четал, Аети и других малых межащих при Кимийских гирлах, населений вновь не имеется; о чем Вашему Высокопревосходительству почтен-нейше донести честь имею.

Фцота капитан Попандопумо

\section{Документ № 6. Рапорт від капітана 1-го рангу С. А. Попандопуло} до намісника Бессарабсъкої області О. М. Бахметьєва. 8 травня 1819 р. Фортеия Ізмаїл. Оригінал. (арк. $92-92$ зө.)

Его Высокопревосходительству Господину генерал-лейтенанту полномочному наместнику Бессарабской области Подольскому военному губернатору и кавалеру Алексею Николаевичу Бахметьеву

Фцота капитана 1-го ранга Попандопуло

Рапорт

Начальник базарчукского карантина и командир военных брантвахт

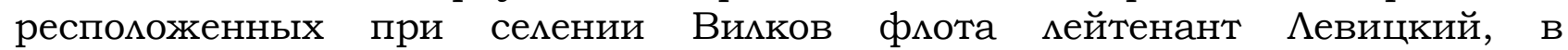
представленном ко мне рапорте прописывает: что минувшего апреля 20 числа приезжали с Коски к вилковской брантвахте два турка сборщика вамы с турецких рыбалок и с гордостью спрашивали: сам $\Lambda и$ он, или по-моему или чьему другому приказанию поставил брантвахту в среднем гирле; которое по их заключениям принадлежит им, и где будто бы никогда наша брантвахта не стоя а. - и еще: половину ширины Дуная, что против, и ниже Вицкова по направлению в Стамбульское гирло, считают принадлежащим им; и с наших рыбалок, которые// производят на сем месте и в среднем гирле мовлю, по претензиям турецких рыбаков он вамщик должен брать десятину; ибо сии 
последние объявили, что если вилковские жители с их воды не будут давать десятины, то они в [...] заберут посуду. На каковые неоснованицьные турецких вамов требования г. Аевицкий объявиц: что границы, которые они назначит не могут и не их до этого дело; за дерзость которая объясняется из настоятельного их требования донесено будет от него начальству. После чего прописанные вамы объявили претензии на вилковских жителей, что якобы они в зимнее время брошенные турецкими рыбалками без всякого призрения на Коске и в других [...стах] шалаши и солилы разорили, и некоторые солилы забрали и другие паломали; но ясного к тому доказательства не представици, кроме только что ссылаются на показания разных с нашей стороны беглецов, которые заключают: что якобы более некому того сделать, как только ближайшим, то есть вилковцам из чего без сомнения можно заключить что как турецких рыбаловов собралось на Коске много, а для выгодной промышлености места// оказалось мало; то вамщики и стараются теперь дмя своей выгоды под разными предцогами распространить свою промышленность. - О чем Вашему Высокопревосходитемьству почтеннейше донести честь имею.

Капитан 1-го ранга Попандопумо

Документ № 7. Рапорт від капітана 1-го рангу С. А. Попандопуло до намісника Бессарабсъкої області О. М. Бахметъєва. 16 березня 1820 р. (№53). Фортеця Ізмаїr. Оригінал (арк. 97).

Его Высокопревосходительству Господину генерал-лейтенанту полномочному наместнику Бессарабской области Подольскому военному губернатору и кавалеру Алексею Николаевичу Бахметьеву

Фцота капитана 1-го ранга Попандопуло

\section{Рапорт}

Командир занимаемового в Килийских гирлах брантвахтенного поста фмота мейтенант Аевицкий рапортом от 12-го сего марта №44 доносит мне: что турецкие [рыбалки] начали на сих днях съезжаться дия своего промысла: с разных мест в Кимийские гирла, на прежние к морю два острова от Коски мевой стороны большого стамбульского пролива, коих набралось до 15 модок: и уже начали бросать в воду рыболовную посуду; о чем Вашему Высокопревосходительству почтеннейше донести честь имею.

Капитан 1-го ранга Попандопуло

Документ № 8. Рапорт від капітана 1-го рангу С. А. Попандопуло до намісника Бессарабсъкої області О. М. Бахметъсва. 16 березня 1820 р. (№54). Фортеця Ізмаїr. Оригінал. (арк. 96-96 з6.)

Его Высокопревосходительству Господину генерал-лейтенанту полномочному наместнику Бессарабской области Подольскому военному губернатору и кавалеру А^ексею Николаевичу Бахметьеву

Фцота капитана 1-го ранга Попандопуло

Рапорт

Командир занимающего брантвахтенного поста в килийских гирлах, фмота мейтенант Аевицкий рапортом от 13-го числа сего м-ца за № 46 донес мне, что разно приежзающие вниз по Дунаю турецкоподданные промышленники, пороспросам его открыли: что турецкое правительство чрез своих чиновнников, всех принадлежащих им рыбаков, и другого скитающегося рода 
мюдей промышленников, проживающих в землянках и куренях на разных островах килийского Дунаю, от Измаила до Черного моря; сгоняют с их жилищ, сжигая их курени и разоряя землянки, запретив вовсе своим рыбалкам как заниматься их промыслом, так и проживать на островах килийского Дунаю, которые перевозятся уже со своим имуществом и заводами на два острова Коски мевой стороны больших стамбульских гирл, на коих откупная у них до сего производимась рыбная мовля; сверх же сего так же донес мне командир брантвахтенного поста занимающего при крепости Измаим// господин фмота капитан мейтенант кавалер Каламатьяно, что проходящие сего м-ца 3-го числа сверху на шаланде турецкоподданные, объявили, что посланы от кошевого старшины с приказом возвратить всех турецкоподданных запорожцев занимающихся рыбным промыслом по килийскому Дунаю; на предмет чего после того и еще прошии 8-м каюков и шаланд о чем Вашему Высокопревосходительству почтеннейше донести честь имею.

Капитан 1-го ранга Попандопумо

\section{Документ №9. Рапорт від капітана 1-го рангу С. А. Попандопуло до намісника Бессарабсъкої області I. М. Інзова. 28 серпня 1820 p. Оригінал (арк. 111)}

Его Превосходительству господину генерал-цейтенанту правящего домжность полномочного наместника Бессарабской области и кавалеру Ивану Никитичу Инзову

Фцота капитана 1-го ранга Попандопуцо

Рапорт

Командир военного брантвахтенного поста, состоящего при килийских гирлах, господин фмота мейтенант в присланном ко мне от 24 числа сего м-ца рапорте, прописывает что в половине августа турецкоподданые и беглые из селения Вилкова рыбалки, жившие до сего по своему произволу куренями на двух российских островах Стамбульского гирла Коскою именуемых, пожегши свои куреня очистили оные острова, и перебрались со своими заводами на противо межащий берег острова Аети, поперпендикуляру с малого Стамбульского гирла на [...], называемый ими масурами, на коем устроя свое жительство выезжают и производят рыбную мовлю в южном большом и малом стамбульських гирлах; почему дабы удалить их вовсе из сих гирл, поставиц// он г-н Аевицкий в прямом стамбуцьском у первого ерика ниже попова гирла/как значится в прилагаемой при сем карте/ до коего у них было заброшено рыболовною посудою, военный крейсерский баркас под. командою артимлериста Костапеля Рафтопуло; о чем Вашему Превосходительству донести честь имею, и докладываю, что я г-ну Аевицкому предписал, помянутый баркас поставить теперь пока у Попова гирла означенного на карте митерою А; по прежде бывшему примеру; а как прописанные рыбаки по нейтральности и не раздеме острова $е$ ти, не домжны и не вправе проживать на занятом ими теперь месте, то посему покорнейше прошу не благоугодно будет к прекращению распространения турецкоподданых своею посудою южного большого и малого стамбульских гирц, повелеть поставить брантвахту у первого ерика ниже Попова гирла, означенного на карте под митерою Б, а дмя обеспечения оной брантвахты на случай всякого покушения в нечаянном нападении, позволить четырем или пяти благонадежным вилковским хозяевам занимающимся рыбным промыслом со своими заводами, быть на острове при брантвахте и стоять куренями. - на что имею честь ожидать Вашего разрешения.

Капитан 1-го ранга Попандопуло 
Карта розмішення рибалок в гирлах Дунаю, з позначенням островів, ио мали залишатися нейтральними (арк. 116)

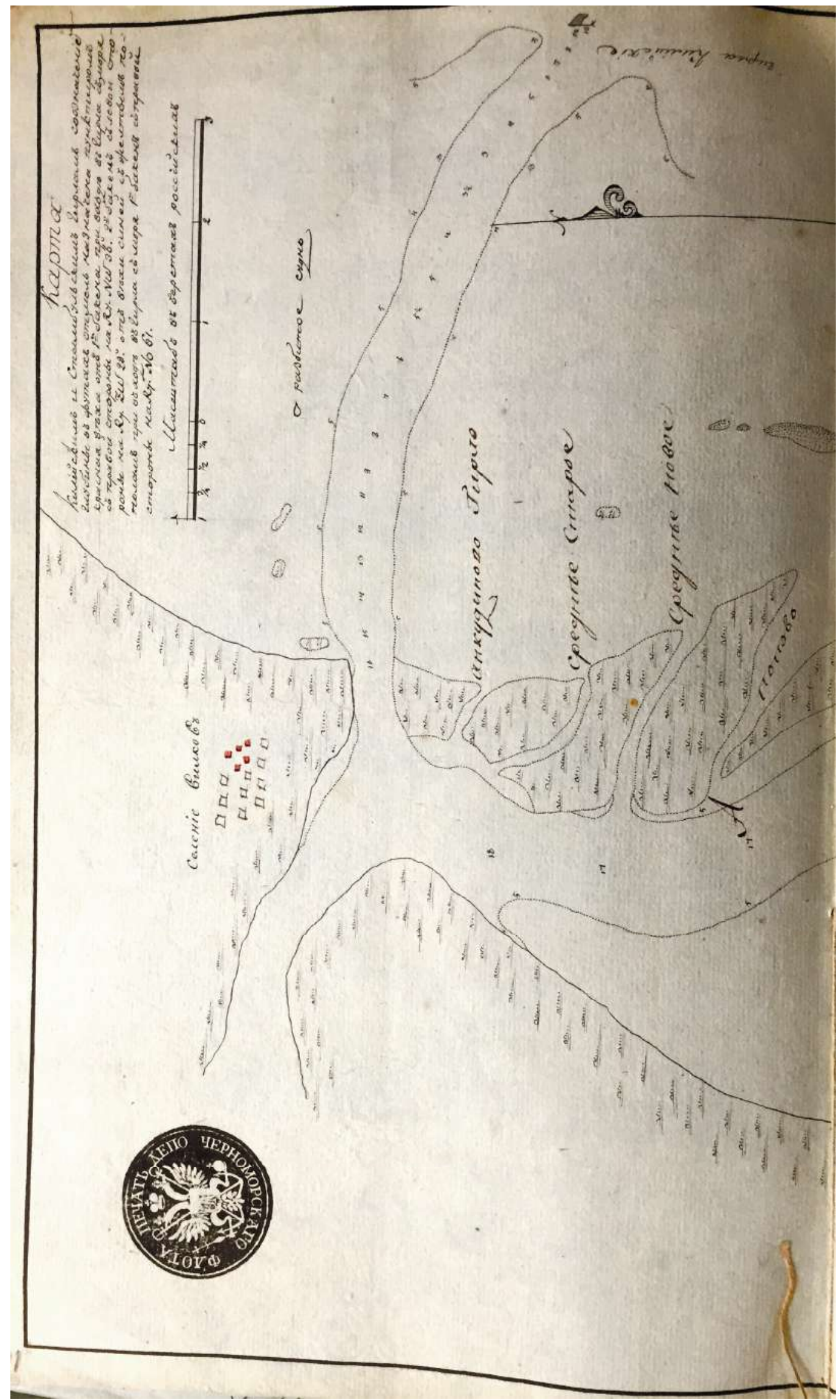


Карта розмішення рибалок в гирлах Дунаю, з позначенням островів, ио мали залишатися нейтральними (продовження)

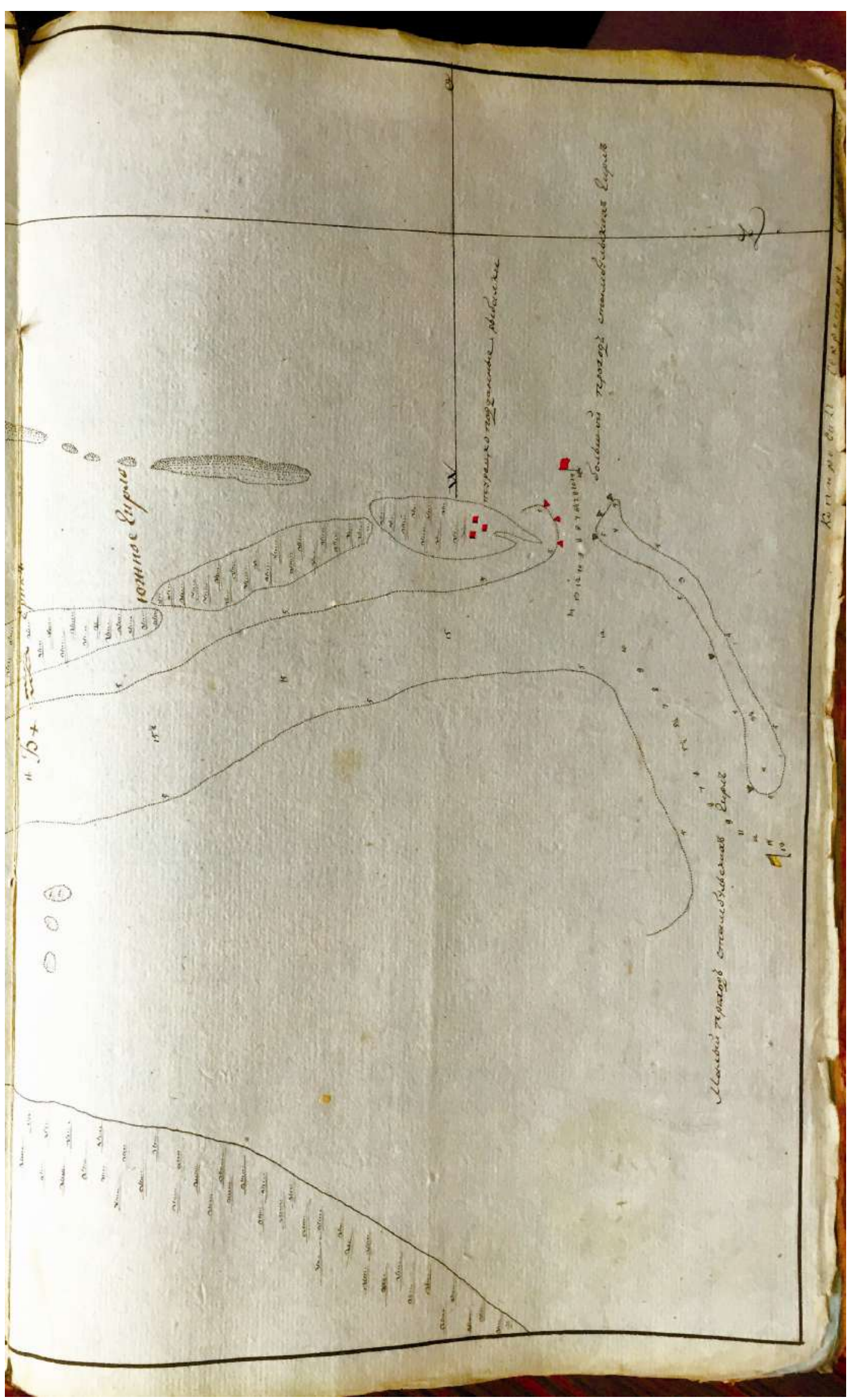


Документ № 10. Рапорт від капімана 1-го рангу С. А. Попандопуло до намісника Бессарабсъкої області I. M. Iнзова. початок rucmonada 1820 р. Оригінал. (арк. 120-120 з6.)

Его Превосходительству господину генерал-лейтенанту правящего должность полномочного наместника Бессарабской области и кавалеру Ивану Никитичу Инзову

Фцота капитана 1-го ранга Попандопумо

Рапорт

Командир военного брантвахтенного поста, занимающаго при ки-

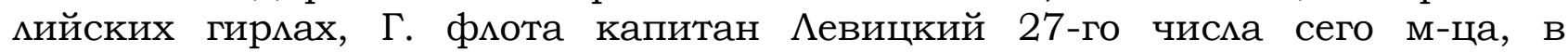
присланном ко мне рапорте прописывает что: с половины октября заметивши он, что турецкоподданные рыбаки по своему промыслу начали съезжаться в килийские гирла на два острова стамбульских таковых же коскою именуемых, приказал чиновнику 12-го класса [.../..] занимающему брантвахтенный пост при стамбульском и поповом гирлах наблюдать за теми рыбаками, который вышепрописанного числа по мичному обозрению и распросе донес ему:// Словесно: что таковых собралось на оные острова уже до 15-ти модок с заводами, где дмя своего житемьства выстроили себе курени и балаганы, и между прочим присваивая оные места к себе, говорят занять те острова для жительства производить рыбную мовлю на взморьи, килийских гирл, и в гирлах, и даже в самом килийском Дунае; /куда скоро и перейдут/ Имеют не токмо позволение, но даже и приказание от своего вамиша турчина Сеинна Аги, а оный имеет от сунинского паши и ибраильского паши; Из чего должно заключить: что турки употребляют все старание присвоить себе как оные острова, так равно и устье стамбульского гирла. причем объясняют, что килийский Дунай по своему течению направление взял по оному, прочие килийских гирл рукава, как-то: Белгородской, Ачаковской, Анкудинов, Крымской, Средний и Попов; приметно засыпает; Из коих кроме среднего, прочие все совсем почти обмелели, стамбульской же углубев, розширев и усилился; то дабы ....[ в тексті справи продовження відсутне. - О. Б.].

Документ № 11. Рапорт від капітана 1-го рангу С. А. Попандопуло до намісника Бессарабсъкої області I. М. Інзова. 20 листопада 1820 р. оригінал. (арк. 122-122 з6.)

Его Превосходительству господину генерал-лейтенанту правящего должность полномочного наместника Бессарабской области и кавалеру Ивану Никитичу Инзову

Фцота капитана 1-го ранга Попандопуцо

\section{Рапорт}

Командир второго отряда судов расположенных при крепости Килия г.

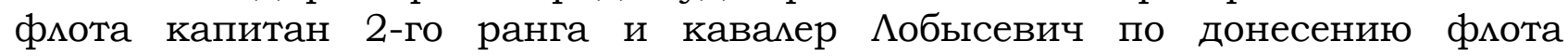
мейтенанта Бабушкина в присланном ко мне рапорте прописывает: что 4-го числа сего м-ця к острову Самману прибыли две кубанские модки и остановились при турецком берегу против коловорота число мюдей хотя и неизвестно но пологать должно до 10-ти человек и начали строить землянки с намерением производить там рыбную цовлю. О чем Вашему Превосходитемьству донести честь имею и докладываю что, // таковых 
турецкоподданых рыбаков на местах где они занимались рыбною мовлею с марта м-ця сего года и по сие время видно не было ибо согнаны быми турецкими чиновниками и курени их все сожжены, а теперь по наступившему зимнему времени как брантвахты с 15-го числа сего м-ца имеют быть сняты то вероятно от тех рыбаков могут последовать большие зцоупотребцения, что и впредь случацось.

Капитана 1-го ранга Попандопумо

\section{Документ № 12. Рапорт өід капітана 1-го рангу С. А. Попандопуло до намісника Бессарабсъкої області I. М. Інзова. 21 грудня 1820 p. Оригінал. (арк. 134-134 з6.)}

Его Превосходительству господину генерал-лейтенанту правящего должность полномочного наместника Бессарабской области и кавалеру Ивану Никитичу Инзову

Фцота капитана 1-го ранга Попандопумо

Рапорт

Командир занимающий брантвахтенные посты в кимийских гирлах, Г. ффмота мейтенант Аевицкий от 17 числа сего месяца доносит мне рапортом: испросив проежзающих по Дунаю турецкоподданых узнал, что часть того же подданства рыбаков, занимающихся сим промыслом на островах Коски, опасаясь наводнения перешли на зимнее время на остров Аетти против селения Вимкова в Чижин Ерик, где расположась выстроили и жилье// Говорят, так же что и в Салманаве / ежащем ниже Килийской крепости в 8 верстах/ на прежнем месте собралось до 8-ми модок на зимовку запорожских рыбаков; О чем Вашему Превосходительству донесть честь имею.

Капитана 1-го ранга Попандопумо

Документ № 13. Рапорт від капітана 1-го рангу С. А. Попандопуло до намісника Бессарабсъкої області I. М. Інзова. 15 березня 1821 p. Оригінал. (арк. 146-146 з6.)

Его Превосходительству господину генерал-лейтенанту правящего доцжность полномочного наместника Бессарабской области и кавалеру Ивану Никитичу Инзову

Фмота капитана 1-го ранга Попандопуцо

Рапорт

Командир военного брантвахтенного поста, содержащей почти в устье реки Репиды, Г. фмлота мейтенант Балилогло рапортом мне донес, что с 6-го по 12-го число сего м-ця, прошло мимо вверенной ему брантвахты, снизу вверх по Дунаю 11-ть рыбачьих каюков, с неводами и посудой, на коих хозяева и работники все некрасовцы и запорожцы, кои при опросе объявики: что они следуют до своих рыбалок из селений Пилипонское и Коска// ибо от турецкого правительства запрещено им там заниматься сей промышменностью, то и переходят они на турецкую границу в Селения на Дунае: при крепостях Тульче, Исакче и городе Галацах межащие; О чем Вашему Превосходительству донести честь имею.

Капитана 1-го ранга Попандопуло 
Документ № 14. Рапорт від капітана 2-го рангу Мобисевича командуючому Дунайсъкою флотилією капітану 1-го рангу Михайлову до намісника Бессарабсъкої області I. М. Інзова. 9 көітня 1823 р. № 621. Konir. (арк. 205-206 36.)

Командир брантвахтенных постов занимающих при селении Вилков г. фмота мейтенант Мойсеев рапортом ко мне сего числа последовавшим за №55 доносит: что Г. штурманский помощник 14-го класса Бавионик 2-й, таковым же к нему пишет что 7-го числа сего м-ца к вверенной ему брантвахте состоящей в устье гирл килийских приезжал из сулинских гирл тамошний начальник асан Ага, с объявлением якобы он получиц от высшего своего начальства повеление, занять для произведения рыбного промысла, стамбульския и новые гирла, который производить будут турецкие кубанцы, изъясняя при том что они поселятся на острове находящемся между новыми и стамбульскими гирлами; теперь же восемь уже модок прибыло и остановились на мусурах с крючковою своею посудою.

И как Г. Мойсеев чрез штурманского //помощника 14-го класса Бавионика 2-го объявил означенному начальнику асан аги, дабы он в дозволении своим рыбакам поселится на коске повременил несколько дней, пока со стороны своего начальства не получит на сие разрешение, на что он был согласен, и обещался через пять дней об узнании распоряжения приехать вторично к брантвахте. При чем спрашивает разрешения дозволить $\Lambda и$ турецкоподданым жителям поселиться на острове/ называемом Коскою/ и занятся рыбным промыслом на том месте где теперь упражняются вилковские жители вблизи состоящей на взморье брантвахты и как уже три года тому назад в отвращение по границе демаем со зма турецкими рыбаками само турецкое правительство не дозволило своим подданным поселятся на Коске; и с того времени не сочтено было за нужное иметь брантвахту в новых гирлах всегда там находившуюся.

Представляя сие на благорассмотрение Вашего Высокоблагородия прошу когда кубанцам дозволено будет поселится на Коске, не благоугодно ми приказать// назначить брантвахту в новые гирла, дабы тем отвратить всякое змо могущее произойти от оных, и употребить все меры к удержание от побегов наших жителей ибо все бежавшие с нашей стороны жители имели всегда пристанище на Коске у кубанцев и о последующем не оставьте Ваше Высокоблагородие меня своею резолюциею. Доношу при том, что я предписал г. Мойсееву чтобы он до того времени ни под каким видом вимковским рыбакам не позволял производить свой промысел в одном месте с кубанцами и даже запретил и сближаться с ними.

В прочем полагать можно, что помянутый асан ага делает сие сам собою дия собственной выгоды и без позволения своего начальства; ибо все упомянутые острова в устьях килийских находящиеся входят в границу по трактам мевой стороны Дуная во владении России и есть они северные 5-ти

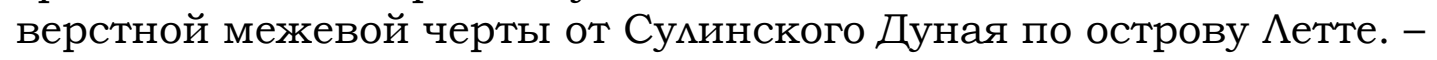

Подиинный подписал капитан 2-го рангу Аобысевич

Документ № 15. Переклад листа тульиинсъкого паші Юнуса до новоросійсъкого та бессарабсъкого генерал-губернатора М. С. Ворониова. 10 червня 1823 р. (арк. $210-210$ зв.)

Всепресветлейший Державнейшей великороссийской империи прекосходитемьный наместник Бессарабской области и управляющий губерниями 
Херсонской, Екатеринославской и Таврической господин генерал-цейтенант $\Lambda$ юбезный мой соседственный благоприятель!

Во исполнение Вашего дружеско-соседственного поручения, полученного сего настоящего июня м-ца 8-го числа мною через консула в Галацах находящегося, о не позволении турецкоподданным кубанцам дмя производства рыбной мовли иметь поселений на местах мирным трактатом заключенных долженствующих оставаться необитаемыми с обоюдных соседственных сторон острова Четала ограниченного Дунаем, я причтенейшим доцгом поставцяю себя Ваше Превосходитемьство по дружественососедственному расположению нашему Вас уведомить о том, что еще прежде получения мною от командующего фцотилиею фрлота капитана 1-го ранга Михайлова в прописываемой Вами симе противности мирного трактата и по одному не позволению брантвахтенного командира военного поста состоящего на взморьи средних килийских гирл, начальник сулинских гир поселившимся было действительно с заводами на означенных нейтральных местах для производства рыбной мовли, заводится оседмостию как не на позволительных местах воспретиц и того же дня со всеми их заводами удалил в свои приделы, без всяких околичностей, как о том я со своей стороны не оставиц без уведомления, и командующего фмотилиею капитна 1-го ранга Михайлова еще от 19-го числа протеженного мая м-ца и с того времени уже более на упомянутых воспрещенных местах более ни кого не имеется я тем что и впредь не надееюсь о сем не// от кого из соседственной стороны о том слышали, что же касается, до позволения того против, заключенного правила, не только со стороны нашей от высшего начальства и от начальника сулинских гирл по справедиивости скажу ни какого не было, как только заниматься для существования их пропитания и то не удалясь от своих приделов, но сие учинено от собственного их произволу под предиогом позволения. - Буде же сверх чаяния моего впредь могут случится подобныя против правиц преступления, чего в протчем я со своей стороны не надеюсь, то прошу покорнейше Вашего Превосходительства приказать кому следует до того не допущать, а меня не оставлять без надмежащего уведоммения, дабы тем не обеспокоить и в мне начальство.

Впрочем уверен будучи совершенно в дружеском нашем расположении, надеюсь что и моя просьба могущая впредь о чем- ибо случиться, со стороны

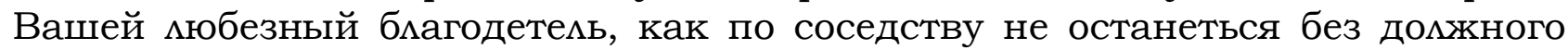
удовлетворения, а я со своей стороны во всякое время готов выполнить все Ваши приятнейшие поручения, в чем только надобность востребует.

Имею честь быть с истинным почтением и совершенною преданостью

Мимостивый государь

Вашего Превосходительства

Усердный и Дружелюбный сосед крепости Тумьчи паша Юнус.

\section{Документ № 16. Рапорт капітана командора Михайлова ново- російсъкому та бессарабсъкому генерал-губернатору М. С. Воронцову. Оригінал. 14 серпня 1823 р. (арк. 219-220).}

Его сиятельству

Господину генерал мейтенанту Новороссийскому генерал-губернатору полномочному наместнику Бессарабской области генерал адъютанту и кавалеру графу Михайлу Семеновичу Воронцову.

Капитан командора Михайлова 
Рапорт

Командир 2-го отряда судов вверенную мне Дунайскую фрлотилию составляющих, расположенных при крепости Кимии г. фмота капитан 2-го ранга и кавалер Һобысевич с полученного им от командира военных брантвахтенных при кимийских гирлах постов г. фрота мейтенанта Мойсеева донесения, по рапорту в новых гирлах; в представленном ко мне рапорте прописывает, что из числа турецкоподданых жителей занимающих рыбным промыслом, на сих днях прибыло из Сулина три рыбачьи модки к острову//Коске,/ которой по трактату домжно быть нейтральным, но еще со стороны мевого берега входит из нашу границу ибо состоит и вернее 5-ти

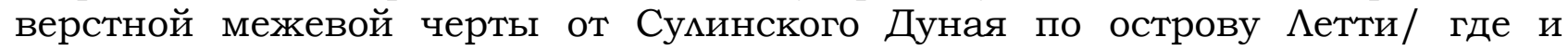
бросили свою крючковую посуду; почему г. Мойсеев дабы обеспечить себя от всякого могущего воспоследовать сомнения в сообщении наших рыбаков с турецкоподдаными, велел находящуюся поблизости Коски наших промышленников посуду, из воды выбрать и удалить ближе к брантвахте на надежное оттоль расстояние; - наши рыбаки стеснясь теперь все вместе, хотя и производять рыбную мовлю подме самой брантвахты, бросая посуду по стамбульскому и новому рукаву, но совсем тем турецкие таковыя, не быв довольны сдеманным для них снисхождением, нарочно подъезжают ближе, и забрасывают посуду рыбаков наших единственно дмя того, что бы совершенно их вытеснить, г. Коробка видя таковую не благонамернность, нарочито подъехавши дия переговоров к прибывшей тогда одной кубанской модке, убеждал их масково, дабы не подъезжали к тем местам где наши занимаются рыболовлею; но один из них по имени// Михайло Куцын, невзирая на масковое с ним обхождение, наделал еще г. Коробке грубостей; говоря "что они посуду наших промышленников найдут и вырежут в новых и очаковских гирлах, если только не очистят для них в весь стамбульский и новый рукава": причем объявил он Куцын о прежде вырезанной у наших

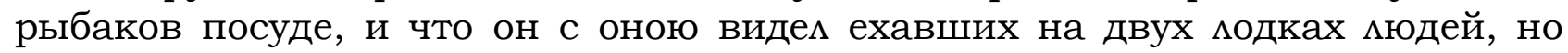
каких именно не сказал. - На сей же модке из числа бывших на ней шести человек, узнаны трое наших жителей бежавших нынешнею зимою, селений: Вилкова Михайло Куцын, и Жибриян Алексей Гмагол и Панкратий Хадаков; кои как полагать должно приезжать не дия промысла рыбной мовли, а единственно дия снискания случая сманить на турецкую сторону находящихся сдесь их родственников.

Подобные сему обстоятельства так же случились в минувшем апреле месяце сего года подозвоцению сунинского начальника, то я с приведением на вид всех осбтоятельств, доносил предместнику Вашего Сиятельства Г. Генерал метенанту и кавалеру Инзову 10-го числа того м-ца за № 49, а о удалении турецких рыбаков с непозволительных им мест, сносился с комендантом крепости Тумьчи пашею Юнус, по распоряжению которого были удалины, и до сих пор не приезжали; О чем донося на благорассмотрение Вашему Сиятельству, имею честь доложить: что о поступках с сим отношусь вторично к помянутому коменданту, и прошу его дабы он не оставиц о удалении их и воспрещении впредь находится в тех местах, сдемать со своей стороны распоряжение.

Капитан командир Михайлов 
Документ № 17. Рапорт капітана командора Михайлова новоросійсъкому та бессарабсъкому генерал-губернатору М. С. Ворониову. Оригінал. 15 січня 1824 р. (арк. $228-228$ з6.).

Его сиятельству Господину генерал адъютанту, генерал мейтенанту полномочному наместнику Бессарабской области и новороссийскому генералгубернатору и кавалеру графу Михайлу Семеновичу Воронцову

Капитан командора Михайлова

Рапорт

На предписание Вашего Сиятельства последовавшее ко мне от 31 декабря, прошлого 1823 года за №4359-м, имею честь почтейнеше донести: что

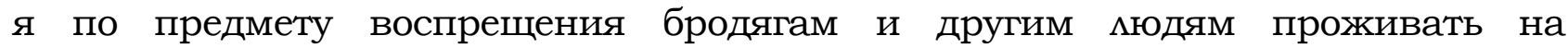
нейтральных островах межащих по реке Дунай, долженствующих по мирным условиям нашим с Портою оставаться необитаемыми, при всяком полученном мною о их шалостях сведений, сношусь с тульчинским пашею, который во удовцетворении моих отношений, как мною замечено, дмя истребления зма посылает по мевому берегу разъезды, кои все// заведении бродяг истребляют. получая при помянутом Вашего Сиятельства повелении на имя означенного паши письма отправия я его на гребном судне с нарочным офицером г. артимлерии унтер мейтенантом Дефабром, которого / как он мне донес/ паша уверил, что с его стороны к исправлению происходить могущего от бродяг зАа, предприняты самые строжайшие меры, и за неисполнение его приказаний 7 человек ослушников наказаны смертною казнею.

Капитан командор Михаймов.

Документ № 18. Переклад листа тульиинсъкого паші Юнуса до новоросійсъкого та бессарабсъкого генерал-губергатора М. С. Ворониова. 30 сіиня 1824 p. (арк. 231-232).

Получивши письмо Ваше дружеское, касательно тайного опасного перехода некоих козаков я отвечаю, что Порта Оттоманская, никогда не переставала строго предписывать своим чиновникам дабы без позволения никого непущать. Такова есть воля Высочайшая, мы никогда не перестаем осматривать письменные дозволения у козаков переходящих от одной границы на другую; мы принимаем деятельнейшие меры примечать за инстранцами и мюдьми без письменного вида, и мы никому не позволяем переходить без паспорта, за всем тем мы впредь удвоим надзоры.

Что касается козаков, которые ходят на рыбную мовлю или на торг ежели один или// два только, то снабжают их паспортами за нашими печатями, известными нашим друзьям Г-ну Капитану и комиссару, но если их четыре или пять, то мы их препровождаем с нашими мюдьми, те кои ходят дмя того же предмета в Житомир или в смежные места, то надо их спросить ежели они не снабжены пропуском от кошевого ими судебного места ими нашего, или ежели они провожаемы каким-нибудь из наших; и как им недозволяется никогда переходить без паспорта, в случаи ежели они скажут, что идут со стороны Тульчи то Вы должны таковых нам//препровождать обратно как преступников, таким же образом надлежит поступать если они говорят, что идут из Тулчи, между тем как идут из Галаца ими из Мачина без надмежащего паспорта. Как мы узнали от некоторых беглецов кои перешли со стороны [Дунавца], что мюди сии переходят границу проходя мимо стражи, то мы долгом считаем Вас о сем уведомить.

Подписал: Юнус, комендант Тульчи и Сулинского прохода. 
Документ № 19. Рапорт командира Дунайсъкої флотілії флота капітана 1-го рангу Заводовсъкого до виконуючого обов'язки новоросійсъкого та бессарабсъкого генерал-губернатора Ф. П. Палєна. 22 көітня 1827 р. Оригінал. (арк. 240)

Его Сиятельству тайному советнику управляющему по гражданской части в Новороссийских губерниях и Бессарабской области и кавалеру графу Федору Петровичу Палену

Командира Дунайской фмотимии фмота капитана 1-го ранга Заводовского

\section{Рапорт}

Из переписки сообщенной мне управляющим измаильскою портовою такможенною заставою, подполковником Витязем 2, произведенной им с измаильскою карантинною заставою, что на острове Четале противу межащаго берега реки Дуная против Измаильского карантина два чемовека заграничные жители обзаведись постоянным жительством и производят там на коммерческие суда приходящие к здешнему порту продажу вина и прочих мелочных вещей, а как таковое пребывание там помянутых жителей противно мирному трактату, по которому остров Четал должен почитатся нейтральным; а равно и действия торговли их// наносящее ущерб Государственным доходам, и в разсуждении сообщения их с жителями нашей стороны. По сим причинам предписал брантвахтенному командиру прописанных жителей с острова Четала немедленно удалить, и жилье их уничтожить; и в предь не позволять им производить там какую-либо торговцю. О чем Вашему Сиятельству наблаго рассмотрение имею честь донести.

Капитан 1-го ранга Заводовский

Взято: Держархів Одеської області. - Ф. 1. - Ф. 214. - Спр. 23 за 1816 р.

\section{Джерема та мітература:}

1. Адриановпольский мирний договор 1829 г. [Електронний ресурс]. - Режим доступу: $\quad$ http://www.vostlit.info/Texts/Dokumenty/Turk/XIX/18201840/Mir_adrianopol 1829/text.htm

2. Бачинська О. Козацтво в “післякозацьку добу" української історії (кінець XVIII - XIX ст.) /Олена Бачинська. - Одеса: “Астропринт”, 2009. - 256 с.

3. Богданович М.Н. История царствования императора Александра I и России в его время. Т. І. СПб., 1869. Приложения. Извцечения из заседаний неофициального комитета.

4. Гросул В. Бухарестский мир 1812 г. и формирование новой юго-западной границы Росии// Формирование территории Российского государства. XVI начало XX В. (границы и геополитика) / Отв. ред. Кудрявцева Е. П. - М. : ИРИ РАН: русский фонд содействия образованию и науке, 2015. - С.130-158 [Електронний ресурс]. - Режим доступа: https://cyberleninka.ru/article/v/buharestskiy-mir-1812-g-i-formirovanienovoy-yugo-zapadnoy-granitsy-rossii

5. Гросул В.Я. Формирование русско-турецкой границы по Бухарестскому миру 1812 года // Формирование границ России с Турцией и Ираном. XVIII начало ХX в. Ч. II. М., 1979. С. 176.

6. Петров А.Н. Война России с Турцией 1806-1812. Т. I-II. СПб., 1885.

7. Держархів Одеської області. - Ф. 1. - ф.214. - Спр. 23 за 1816 р. - 405 арк. 
8. Записки графа А. Ф. Аанжерона: Война России с Турцией. 1806 - 1812 гг. // Русская старина. - 1907-1909.

9. Кухарук О. Задунайські козаки в планах російського командування в війну 1828-1829 рр.// Чорноморська минувшина. Записки віддіну історії козацтва на півдні України Науково-дослідного інституту козацтва Інституту історії України НАН України: Зб. наук. пр. - Вип. 3. - Одеса, 2009. - С. 71-75.

10. Національний архів Республіки Молдова. - Ф. 2. - Оп. 1. - Спр. 220. - Арк. $56,159$.

11. Никифоров А. А. Русско-румынские отношения и формирование границы / / Военно-исторический журнал. - 1990. - № 12. - С.3-8.

12. Чертан Е. Е. Новые данные об установцении государственной границы России по Дунаю в 1813-1817 годах // Вековая дружба. - Кишинев, 1961. C. 254-257.

\section{References:}

1. Adrianovpol'skiy mirniy dogovor 1829 g. [elektronniy resurs]. - Rezhim dostupu: http://www.vostlit.info/Texts/Dokumenty/Turk/XIX/18201840/Mir_adrianopol_1829/text.htm

2. Bachyns'ka O. (2009) Kozatstvo v "pislyakozats'ku dobu” ukrayins'koyi istoriyi (kinets' XVIII - XIX st.). Olena Bachyns'ka. Odesa: “Astroprynt”, 2009. 256 s.

3.Bogdanovich M.N. Istoriya tsarstvovaniya imperatora Aleksandra I i Rossii v ego vremya. T. I. SPb., 1869. Prilozheniya. Izvlecheniya iz zasedaniy neofitsial'nogo komiteta.

4. Grocul V. (2015) Bukharestskiy mir 1812 g. i formirovaniye novoy yugozapadnoy granitsy Rosii. Formirovaniye territorii rossiyskogo gosudarstva. XVI nachalo XX V. (granitsy i geopolitika), Otv. red. Kudryavtseva E. P. - M. : IRI RAN: russkiy fond sodeystviya obrazovaniyu i nauke, 2015. S.130-158 [elektronniy resurs]. - Rezhim dostupa: https://cyberleninka.ru/article/v/buharestskiy-mir1812-g-i-formirovanie-novoy-yugo-zapadnoy-granitsy-rossii

5. Grosul V. YA. (1979) Formirovaniye russko-turetskoy granitsy po Bukharestskomu miru 1812 goda // Formirovaniye granits Rossii s Turtsiyey i Iranom. XVIII - nachalo XX v. CH. II. M., 1979.

6. Petrov A.N. Voyna Rossii s Turtsiyey 1806-1812. - T. I-II. - SPb., 1885.

7. Derzharkhiv Odes'koyi oblasti (State archives of Odessa region). F. 1. Op. 214. Spr. 23 za 1816 r. 405 ark.

8. Zapiski grafa A. F. Lanzherona: Voyna Rossii s Turtsiyey. 1806 - 1812 gg., Russkaya starina. - 1907-1909.

9. Kukharuk O. (2009) Zadunays'ki kozaky v planakh rosiys'koho komanduvannya v viynu 1828-1829 rr., Chornomors'ka mynuvshyna. Zapysky viddilu istoriyi kozatstva na pivdni Ukrayiny Naukovo-doslidnoho instytutu kozatstva Instytutu istoriyi Ukrayiny NAN Ukrayiny: Zb. nauk. pr. Vyp. 3. Odesa, 2009. S. 71-75.

10. Natsional'nyy arkhiv Respubliky Moldova. F. 2. Op. 1. Spr. 220. Ark. 56, 159. 11. Nikiforov A.A. (1990) Russko-rumynskiye otnosheniya i formirovaniye granitsy, Voyenno-istoricheskiy zhurnal. 1990. № 12. S. 3-8.

12. Chertan E.E. Novyye dannyye ob ustanovlenii gosudarstvennoy granitsy Rossii po Dunayu v 1813-1817 godakh, Vekovaya druzhba. Kishinev, 1961. S. 254-257. 


\section{Казаикое пограничье в большой политике и повседневной жизни межкуу двумя русско-туреикими войнами первой трети XIX в. (по материалам Госархива Одесской области)}

В публикаиии вниманию читателей предлагаются документы, которые раскрывают повседневную жизнь "туреиких" казаков - запорожских $и$ некрасовских - на османо-российской граниие, а также локализуют места их расположения в Подунавье в начале XIX в. Предложенные материаль представляют собой переписку российской и османской администраиии по разграничению гранииы между двумя русско-туреикими войнами 18061812 г2. и 1828-1829 г2., карты размешения задунайских и некрасовских казаиких рыбаков. Они позволяют выяснить, ито между казаками разных групп оставались тесные контакты на хозяйственной почве, во многом их сохраняла османская приграничная администраиия и коменданты дунайских крепостей. В то же время российская пограничная администраиия пыталась вытеснить "туреиких" рыбаков-казаков, чтобы избежать их обиению с родственниками в дунайских городах и крепостях.

Документы публикуются впервые.

ключевые слова: некрасовские (кубанские) казаки, задунайские (туреикие) запорожиы, Дунай, русско-туреикая война 1806-1812 г2., русскотуреикая война 1828-1829 г2., остров Аете, остров Четал, Государственный архив Одесской области.

Отримано 21.11.2018 p. 